\title{
A FOTO ERRADA NA CAPA CERTA: CASAMENTO GAY, FETICHISMOS VISUAIS E PRODUÇÃO DE SENTIDO NA RECEPÇÃO MIDIÁTICA
}

\author{
The wrong picture in the right cover: gay marriage, visual fetichism and making \\ sense in midiatic reception
}

\section{La mala foto en la buena portada: el matrimonio gay, fetichismo visual y produc- ción del sentido en la recepción mediática}

Camilo Vannuchi ${ }^{1}$

\section{Resumo}

Neste artigo, investigamos de que maneira a foto publicada numa capa de revista pode influenciar negativamente as práticas de consumo da edição ao permitir que a produção de sentido (na recepção) contradiga o pretendido pelo emissor (na enunciação). Comparamos duas capas sobre o mesmo tema, publicadas por revistas distintas (a Time e a Época São Paulo), combinando semiótica, análise do discurso e teorias da enunciação. Por fim, recorremos à teoria da enunciação da recepção publicitária proposta por Trindade (2008b) para sugerir sua aplicação no estudo da recepção jornalística.

Palavras-chave: produção de sentido, enunciação, recepção, fetichismo visual, revista Época São Paulo.

\begin{abstract}
In this paper, we explored how a photo published in a magazine cover can negatively influence the consumption practices of an issue by enabling the making sense (in reception) contradicts the purpose first intended (in enunciation). For that, we compared two covers about the gay marriage, published by different magazines (Time and Época São Paulo), mixing semiotics, discourse analysis and theory of enunciation. Finally, we resort to the theory of advertising enunciation in reception, as conceived by Trindade (2008b), to propose its application in the study of news reception.
\end{abstract}

\footnotetext{
${ }^{1}$ É jornalista, mestrando no Programa de Pós-Graduação em Ciências da Comunicação da ECA-USP, pesquisador na área de concentração Estudo dos Meios e da Produção Mediática. Foi editor da revista Época São Paulo de 2010 a 2012. E-mail: camilovannuchi@ usp.br. Tel. (11) 99299-0158. Rua Caraíbas, 1336, ap. 32, CEP 05020-000, São Paulo, SP.
} 
A foto errada na capa certa: casamento gay, fetichismos visuais e produção de sentido na recepção midiática

de Camilo Vannuchi

264

Keywords: making sense, enunciation, reception, visual fetishism, Época São Paulo magazine.

\section{Resumen}

En este trabajo, hemos explorado cómo una foto publicada en la portada de una revista puede influir negativamente en las prácticas de consumo de la edición, permitiendo que la producción de sentido, en la recepción, contradice el pretendido en la enunciación. Se comparan dos casos sobre el mismo tema, publicados por Time y Época São Paulo, mediante la combinación de semiótica, análisis del discurso y teorías de la enunciación. Por último, se recurre a la teoría de la enunciación publicitaria en la recepción (Trindade 2008b) para proponer su uso en el estudio de la recepción periodística.

Palabras-clave: producción de sentido, enunciación, recepción, fetichismo visual, revista Época São Paulo.

\section{INTRODUÇÃO}

No dia $1^{\circ}$ de março de 2013, entrou em vigor uma norma, publicada em 18 de dezembro do ano anterior pelo Tribunal de Justiça de São Paulo, orientando os cartórios paulistas a realizar casamentos entre pessoas do mesmo sexo. Tecnicamente, o que o Tribunal fez foi incluir o casamento gay numa lista intitulada Normas de Serviço da Corregedoria Geral da Justiça, uma espécie de cardápio com as atividades que devem ser oferecidas pelos cartórios do estado.

Até aquela data, a Bahia era o único estado brasileiro a equiparar os direitos dos casais homossexuais e heterossexuais quanto à permissão para o matrimônio. Antes, valia para os paulistas a mesma regra vigente no Distrito Federal e nos outros 24 estados: companheiros do mesmo sexo tinham de solicitar a um juiz uma autorização especial, e dependiam de sua anuência para verem acatada sua solicitação. O hiato jurídico gerava constrangimento e insegurança. Desde então, a oficialização do casamento se tornou imediata - e a certidão fica pronta em até 15 dias.

A novidade inspirou os editores da Revista Época São Paulo, publicação mensal da Editora Globo que circula na região metropolitana junto com a semanal Revista Época, a tratar do assunto na reportagem de capa da edição de abril, publicada em 29 de março. "Casamento gay - Como a conquista desse novo direito civil em São Paulo afeta 
A foto errada na capa certa: casamento gay, fetichismos visuais e produção de sentido na recepção midiática

de Camilo Vannuchi

a vida de homens e mulheres homossexuais", dizia a chamada, sobreposta à foto de dois rostos femininos na iminência de um beijo.

Fig. 1

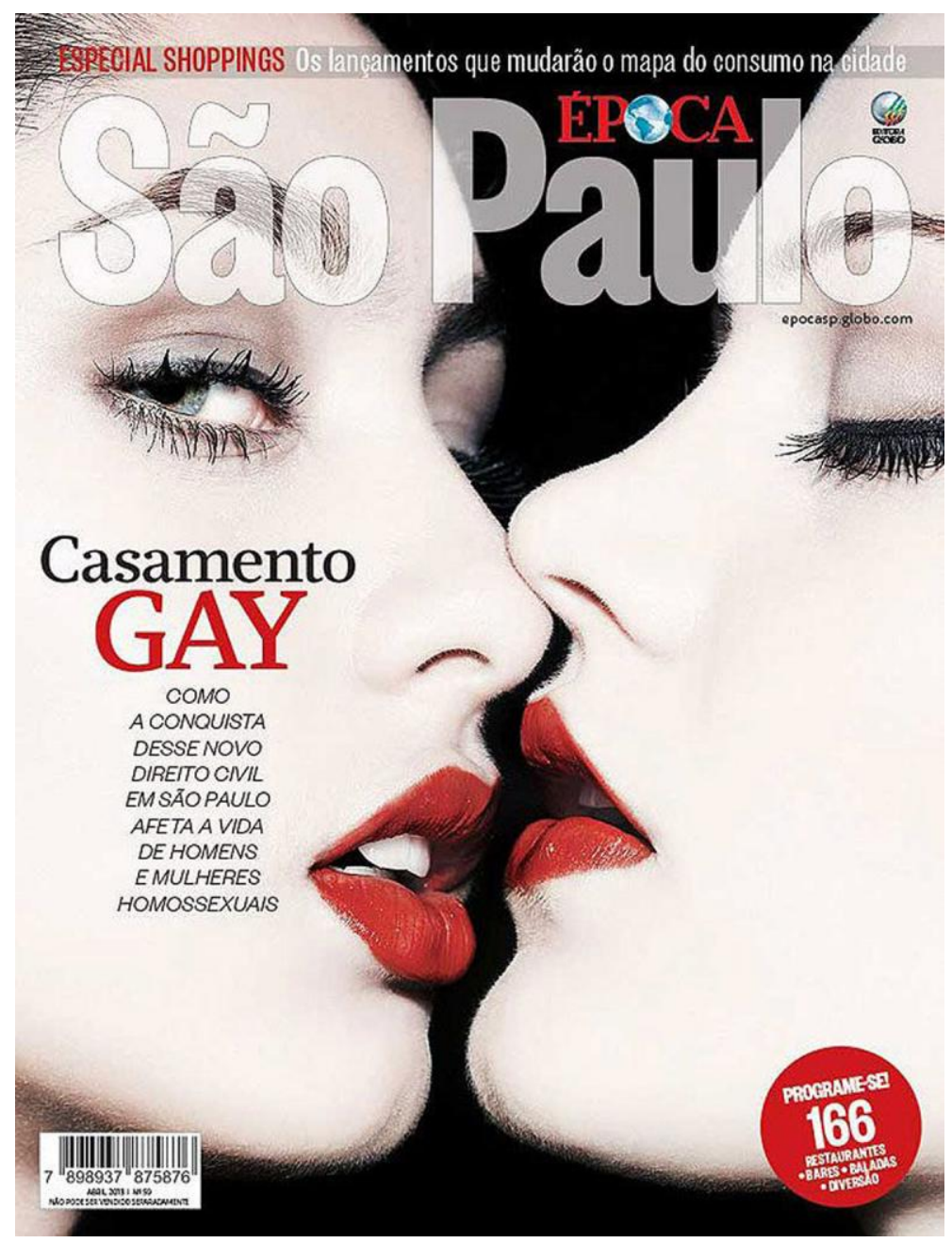

A revista foi pioneira ao celebrar a decisão do TJ paulista. Sete dias depois, a legalização do casamento gay estamparia as capas das principais revistas semanais do país, a Veja e a Época, motivadas por uma declaração da cantora Daniela Mercury, que acabara de assumir publicamente estar casada com uma mulher.

A ousadia da pauta, frequentemente preterida pela grande "imprensa"; o texto coeso e bem fundamentado das jornalistas Aline Ribeiro e Denise Dalla Colletta; a abordagem favorável à revisão da lei, evidenciada na escolha por palavras como "conquista" e "direitos" para compor a chamada de capa, tudo fazia supor que a edição seria bem recebida pelos leitores afeitos ao tema, fossem eles homossexuais, ativistas dos 
A foto errada na capa certa: casamento gay, fetichismos visuais e produção de sentido na recepção midiática

de Camilo Vannuchi

direitos civis ou quaisquer cidadãos simpáticos à novidade noticiada. A recepção, no entanto, não foi tão efusiva quanto seria possível imaginar, como veremos.

No mesmo dia, a Time publicou uma capa sobre o mesmo tema. "O casamento gay já ganhou - A Suprema Corte ainda não se decidiu, mas a América sim", dizia a chamada.

Fig. 2

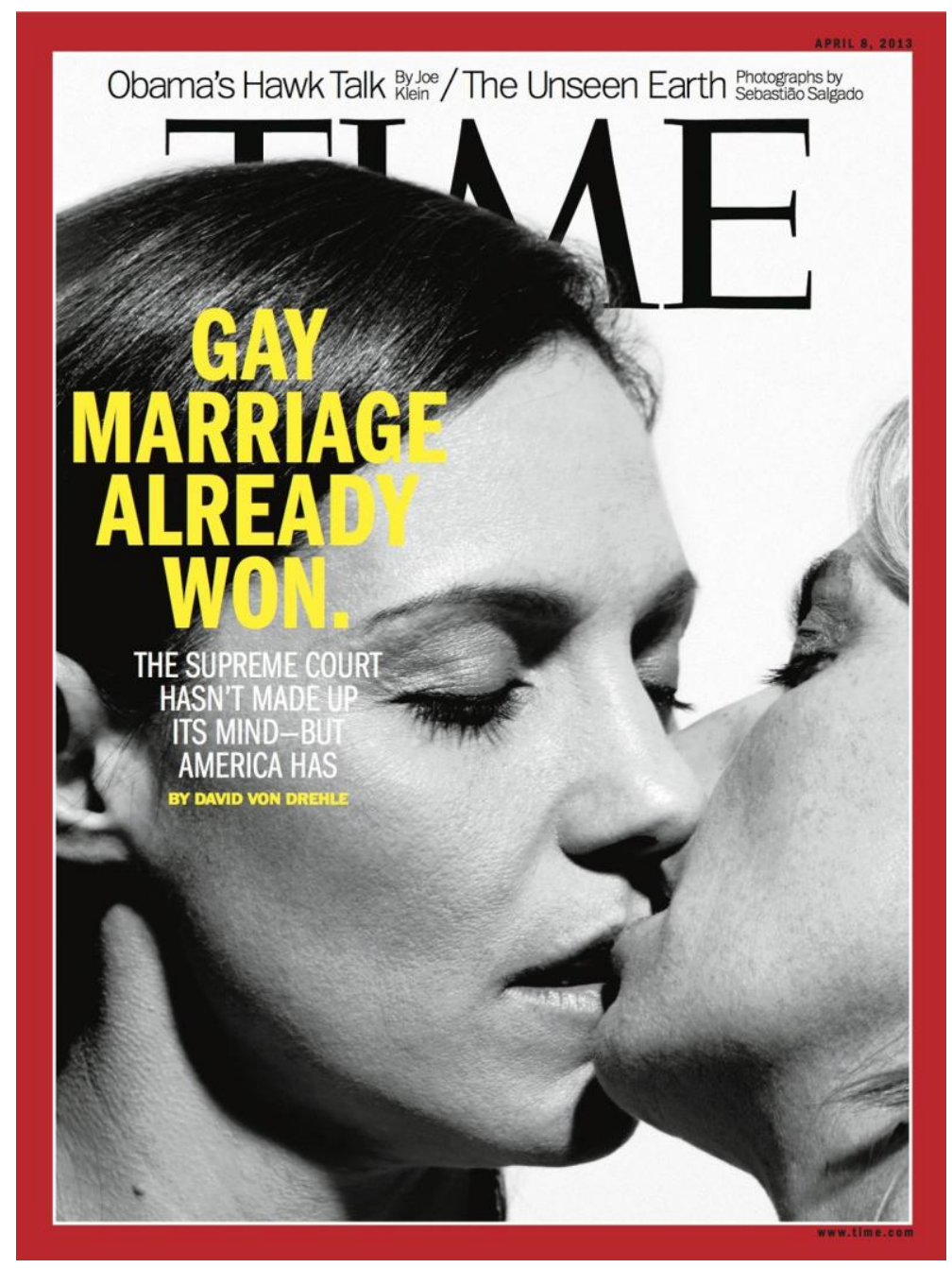

O texto fazia referência a um processo iniciado na mesma semana na instância máxima da justiça dos Estados Unidos, obrigando o colegiado a decidir sobre a legalidade da Proposição 8, uma emenda de 2008 que vetara o casamento gay na Califórnia após apenas seis meses de vigência - e 18 mil certidões expedidas para casais do mesmo sexo entre maio e novembro daquele ano.

Com o tema novamente na agenda, a Time se propôs a mostrar, com base em pesquisas de opinião e no arcabouço legal dos estados (oito instituíram a união civil e 
A foto errada na capa certa: casamento gay, fetichismos visuais e produção de sentido na recepção midiática

de Camilo Vannuchi

dez aprovam o casamento gay), que a maior parte dos cidadãos americanos é favorável a esse direito (ver Drehle 2013). De fato, a Proposição 8 seria derrubada pela Suprema Corte em 27 de junho de 2013.

Para a edição, foram impressas duas opções de capa, de modo que o leitor/consumidor poderia escolher qual adquirir. Em ambas, um beijo gay era estampado, em close, numa foto PB. Numa das opções, um beijo entre dois homens; na outra, um beijo entre mulheres. Neste artigo, observamos com maior cuidado a versão feminina, dada a semelhança com a similar brasileira.

É na observação simultânea de ambas as capas, rapidamente possibilitada pela internet e pelo amplo compartilhamento das duas imagens nas redes sociais, que os detalhes e as especificidades de cada revista se evidenciam e suscitam especulações. Embora as pautas não sejam exatamente a mesma, e apesar da necessidade de se considerar que o debate sobre direitos civis e orientação sexual não esteja no mesmo patamar evolutivo nos dois países, a semelhança entre as fotografias usadas nas capas instiga à comparação feita na ocasião e recuperada neste artigo.

Tanto a Time quanto a Época SP divulgaram reproduções de suas capas nas redes sociais em 28 de março de 2013, véspera da chegada às bancas. A postagem em que a Time expôs sua capa no Facebook indicava 3.770 "likes" e 3.939 "shares" em 5 de junho (data da consulta). Com penetração mais modesta, e um número de fãs no Facebook 30 vezes menor, a Época SP obteve, até a mesma data, 549 compartilhamentos e 163 "curtidas" com o post em que, por sua vez, divulgou sua capa. À postagem seguiam 54 comentários, sem contar os publicados nas páginas de quem compartilhou a imagem. Esses comentários, juntamente com os 22 publicados no blog Faz Caber, vinculado ao site da Revista Época, no qual o diretor de arte Marcos Marques revela os bastidores da produção das capas, serviram de apoio para o estudo de recepção aqui apresentado.

\section{ENUNCIAÇÃO: CONQUISTAS E DIREITOS}

Seguindo o protocolo das redes sociais, ambas as revistas, a Time e a Época São Paulo, divulgaram suas capas no Facebook um dia antes da chegada às bancas, de modo a despertar curiosidade no público e atrair compradores. A coincidência editorial, por um lado, poderia ser comemorada pela equipe da publicação brasileira: ao debruçar-se sobre o mesmo tema que a maior revista dos Estados Unidos, precisamente no mesmo 
A foto errada na capa certa: casamento gay, fetichismos visuais e produção de sentido na recepção midiática

de Camilo Vannuchi

dia, um título regional com cinco anos de estrada revela "timing" e se mostra "antenada" com o debate internacional, com o espírito do tempo. Por outro lado, a coincidência favorece a comparação e, aos poucos, expõe certas diferenças de tratamento e algumas distâncias subjetivas entre as duas capas, especialmente no campo da ousadia.

Em primeiro lugar, o beijo: apenas sugerido na versão brasileira, ele é deflagrado na versão estrangeira. Em segundo lugar, a opção pela "história real": enquanto Época SP recorreu a modelos para a produção da foto, premida pelo fator tempo, a imagem da Time foi feita com personagens - um casal gay "de verdade", como anotado por alguns leitores - gesto que inspira credibilidade e identificação. Um terceiro fator seria a existência de duas versões de capa para a edição americana:

Fig. 3
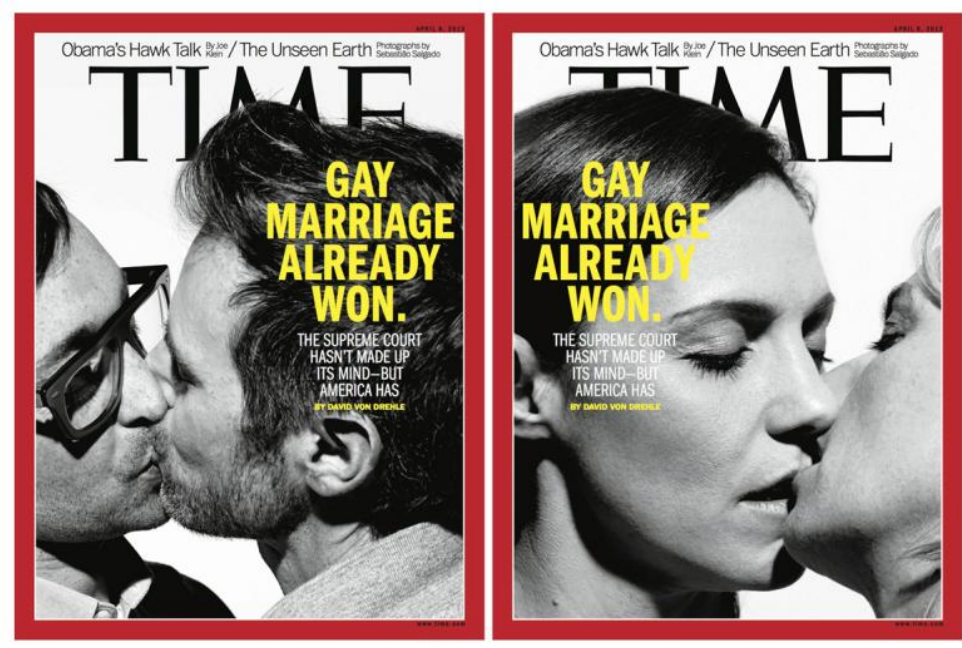

Bem sucedida - não apenas por permitir ao leitor escolher, mas também por universalizar a pauta, dialogando de maneira explícita com os dois gêneros e se protegendo de eventuais acusações de sexismo -, a estratégia da Time fora cogitada também pelo título paulistano, mas descartada às vésperas da publicação. "Deveria ser um casal de mulheres e um casal de homens, e a tiragem dividida ao meio com as duas capas", escreveu o diretor de arte no Faz Caber. Com o cancelamento da edição dupla, a revista promoveu uma enquete nas redes sociais convidando o público a escolher entre três versões. Uma delas sugeria um beijo entre homens: 
A foto errada na capa certa: casamento gay, fetichismos visuais e produção de sentido na recepção midiática

Fig. 4

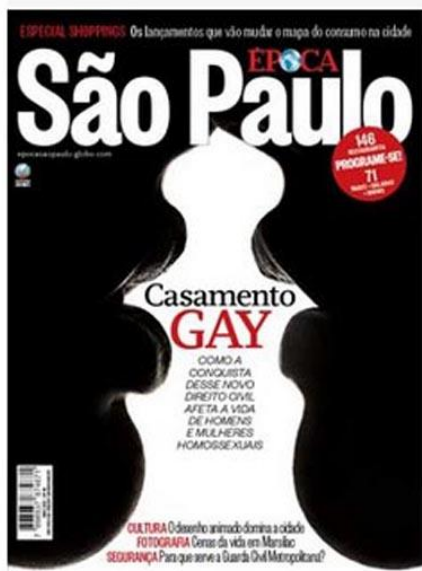

Opção 1

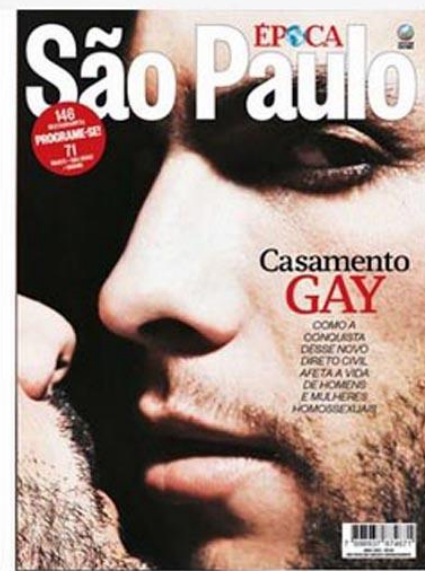

Opção 2

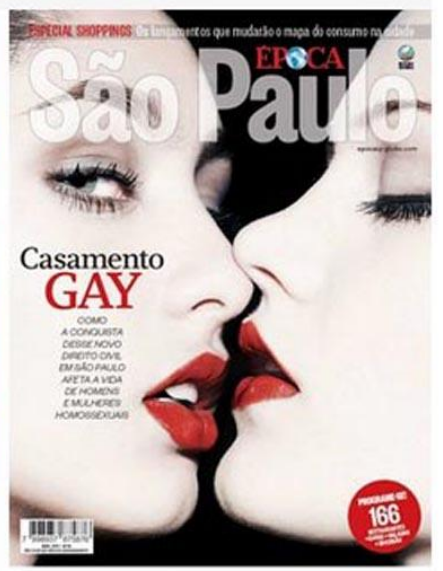

Opção 3

Finalmente, um quarto elemento que ajuda a reforçar a percepção de que a capa da Time é mais "ousada" do que a da Época SP - embora possa afastar os leitores mais conservadores, justamente por ser tão explícita, o que não acontece diante da capa da revista brasileira, mais palatável às diversas idades e convicções - é a chamada de cada uma. Considerando-se as manchetes, o embate se dá entre "Casamento gay" e "O casamento gay já ganhou". De maneira rudimentar, a opção por destacar simplesmente a expressão casamento gay - uma frase sem verbo que, no enunciado, desempenha a função de um simples substantivo composto - resulta numa formulação mais fria e evasiva se comparada à sentença - com sujeito, verbo e predicado - estampada na outra revista.

De certa forma, "casamento gay" introduz não exatamente uma notícia, mas um tema, um tópico. E o faz sem se comprometer, sem assumir uma posição, um ponto de vista ou um discurso. "O casamento gay já ganhou", por sua vez, tem a força das frases com verbo, indicando não algo estático e conhecido, mas uma mudança, uma novidade, uma ação. Aqui, o leitor percebe que algo aconteceu com o casamento gay - e cabe a ele abrir a revista para saber o que foi. A chamada norte-americana dá um passo além ao escolher um verbo que revela vitória, triunfo. A frase personifica o casamento gay comparando-o a um candidato ou atleta, como se o julgamento pela suprema corte se equiparasse a um pleito ou a uma partida. Uma outra leitura possível possibilita vislumbrar não um processo eleitoral ou um jogo, mas uma batalha travada entre legiões ou exércitos adversários.

Num momento em que o resultado desse "jogo", dessa "batalha" jurídica, ainda não era conhecido, a expressão "o casamento gay já ganhou" se traveste de torcida, de 
A foto errada na capa certa: casamento gay, fetichismos visuais e produção de sentido na recepção midiática

de Camilo Vannuchi

aposta. De maneira mais forte (e ousada) do que o similar brasileiro, a chamada da Time pode ser lida como quem lê uma bandeira, uma faixa, um grito de guerra. A mesma sentença, substituindo-se o sujeito por outro, é mais frequentemente ouvida às vésperas de uma final de campeonato, quando há confiança na vitória de um dos adversários. Às vezes, induz àquilo que, no Brasil, se convencionou chamar de salto alto - o conhecido "já ganhou" que costuma assombrar os favoritos.

Aplicado à capa, o enunciado é rapidamente traduzido em posicionamento editorial. Em outras palavras, é graças ao interdiscurso, esse emaranhado de referências conhecidas a priori e que Maingueneau chamou de "memória não psicológica presumida pelo enunciado enquanto inscrito na história" (Maingueneau 1989), que a sentença adquire um sentido militante. Ainda segundo Maingueneau, "a toda formação discursiva é associada uma memória discursiva, constituída de formulações que repetem, recusam e transformam outras formulações" (grifo dele). Se todo discurso tem um antes, uma rede de postulados ou de enunciados que o antecede e a partir da qual o discurso é elaborado, é esse interdiscurso que, no exemplo, dá concretude à "aposta" da Time, provocando empatia ou asco, conforme as posições ou preferências do leitor.

Assim, toda formulação estaria colocada, de alguma forma, na intersecção de dois eixos: o "vertical", do pré-construído, do domínio de memória, e o "horizontal", da linearidade do discurso, que oculta o primeiro eixo, já que o sujeito enunciador é produzido como se interiorizasse de forma ilusória o pré-construído (Maingueneau, 1989: 115).

Voltando os olhos mais uma vez para a Época SP, é oportuno reparar que a produção de sentido da enunciação não seria idêntica à que acabamos de relatar se não tivéssemos conhecimento da capa da Time - ou se ela jamais tivesse existido. Antes de nos enveredarmos pela observação dos dialogismos e polifonias presentes na capa paulistana, e antes de estudarmos sua recepção pelo viés da circulação, o exercício que propomos a seguir é o desenvolvimento de uma breve análise de conteúdo, combinando elementos da semiótica e da análise do discurso, na esperança de descobrir o que os editores "quiseram dizer" ao publicá-la, independentemente do que mostra a capa americana.

Grosso modo, uma capa de revista pouco difere de uma peça publicitária, uma vez que suas funções se assemelham às do anúncio: divulgar um produto, atrair compradores, formar identidade de marca, influenciar hábitos de consumo. Assim, o que diz a "embalagem" de Época SP? Que apelos de consumo apresenta? Que elementos discur- 
A foto errada na capa certa: casamento gay, fetichismos visuais e produção de sentido na recepção midiática

de Camilo Vannuchi

sivos os editores usaram para atrair público? Uma capa de revista, quando bem executada, diz muito sobre o tipo de jornalismo que ela pratica. Isso se dá nos diferentes níveis da retórica, textual ou visual, desde os mais óbvios, como o assunto que iça às chamadas de capa, até os mais sutis, como o "tom" empregado no texto ou os conceitos transmitidos nas fotos utilizadas. Ao analisar uma capa, é possível compor o ethos da publicação, a imagem que os editores (e, por extensão, "a revista") constroem de si mesmos.

Maingueneau foi buscar em Aristóteles o conceito de ethos, a imagem que os oradores constroem de si mesmos ao proferir seus discursos, e o emprega referindo-se à retórica adjacente aos elementos constitutivos do discurso na enunciação: uma projeção idealizada dos receptores nos discursos (Trindade, 2008a: 74).

O que temos, com base na análise de conteúdo da capa estudada neste artigo, é uma revista atenta ao zeitgest, o "espírito do tempo", e independente o bastante para dedicar a reportagem principal de uma edição a um assunto que a maioria das revistas não aborda nem em matérias menores. Seu ethos é o de uma publicação disposta a repercutir e polemizar, tratando temas complexos de maneira didática ("como a conquista desse novo direito...") e elegante (predomínio do branco, poucos elementos e cores, apenas duas chamadas...).

Recorrendo à semiótica greimasiana, precisamente ao percurso gerativo de sentido, podemos inferir, sempre considerando a intenção do enunciador no ato de enunciação, uma oposição semântica fundamental entre submissão (disfórico) e soberania (eufórico), ou entre inferioridade (disfórico) e plenitude (eufórico). Os signos ali presentes lidam com esses deslocamentos. O que a imagem transmite, em conjunção com o texto que o ladeia, é a fisionomia austera e segura de um casal ciente de seus direitos, apto a assumir seu relacionamento sem se esconder, sem desviar os olhos nem baixar a cabeça. $\mathrm{Na}$ imagem, o olhar da mulher da esquerda surge oblíquo e inclinado, descendente, com nobreza e altivez. Eu posso, ela parece dizer. Olhe à vontade - e não me julgue. 
A foto errada na capa certa: casamento gay, fetichismos visuais e produção de sentido na recepção midiática

de Camilo Vannuchi

Quadro 2: Quadrado semiótico de Floch

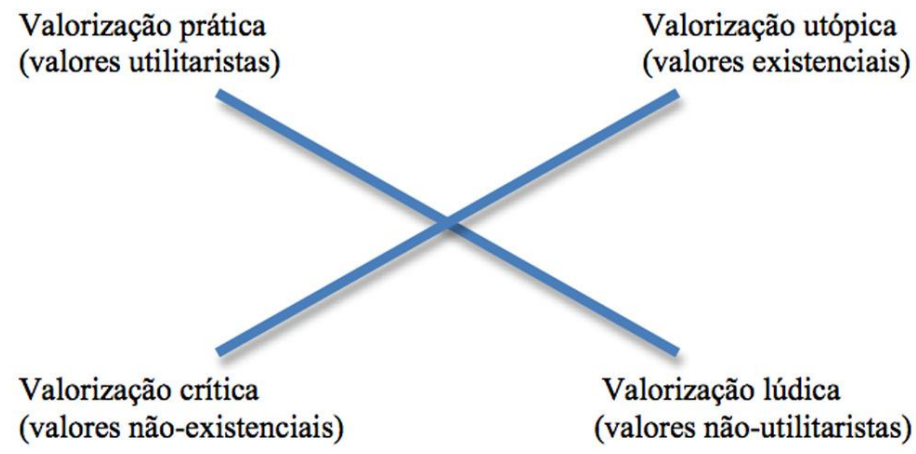

Mas é em Floch que encontramos de maneira mais evidente a interlocução entre a semiótica e a valorização publicitária do objeto analisado. Segundo Souza e Santarelli (2008), o autor é "reconhecidamente o intelectual que mais contribuiu para o uso da pesquisa semiótica nas áreas de marketing e comunicações", aplicando a teoria e o modelo greimasianos ao estudo na enunciação. Com base na teoria do percurso gerativo de sentido formulado por Greimas,

...o autor constrói um quadrado semiótico e estabelece uma tipologia dos modos de valorização criados pela publicidade. De acordo com o autor, as descrições dessas valorizações são: (1) prática: correspondente aos valores de uso, concebidos como contrários aos valores de base (são valores utilitários, como manuseio, conforto, potência...); (2) utópica: correspondente aos valores de base concebidos como contrários aos valores de uso (valores existenciais como identidade, liberdade, vida aventureira...); (3) lúdica: correspondente à negação dos valores utilitários (a valorização lúdica e prática são contraditórias entre si, os valores lúdicos são o luxo, o refinamento...); (4) crítica: correspondente à negação dos valores existenciais (a valorização crítica e a valorização existencial são contraditórias entre si; as relações de qualidadelpreço e custo/benefício são próprias dos valores críticos) (Souza e Santarelli 2008: 147).

Visualmente, o quadrado proposto por Floch assume o seguinte aspecto:

Quadro 1: Aplicação do quadrado semiótico de Greimas à capa da Época São Paulo

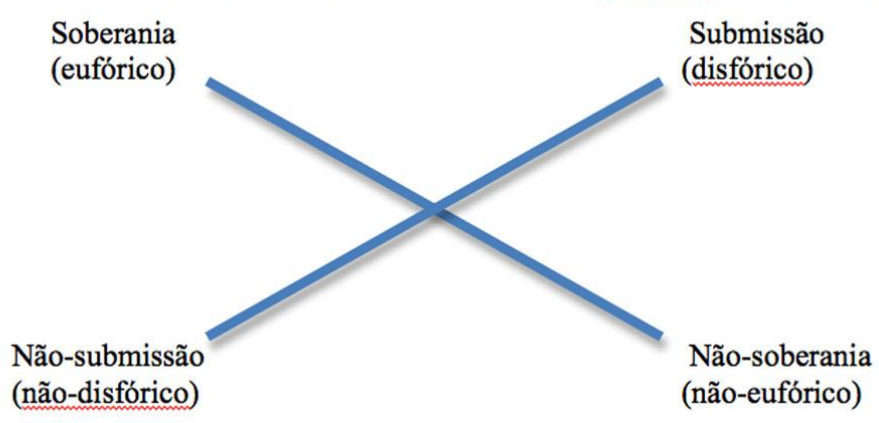


A foto errada na capa certa: casamento gay, fetichismos visuais e produção de sentido na recepção midiática

de Camilo Vannuchi

A aplicação do quadrado semiótico de Floch ao estudo da enunciação da capa da Época SP nos permite perceber a intenção dos editores de destacar a valorização utópica na composição texto-imagem. O que o retrato das duas mulheres deveria inspirar nos potenciais leitores/consumidores são os valores existenciais referidos por Souza e Santarelli (2008). Identidade e liberdade, sim, mas principalmente soberania, plenitude, autonomia, poder de decisão (sobre sua vida, seus desejos, seu comportamento sexual). Não apenas a postura e o olhar expressos no retrato confirmam essa intenção, mas também o emprego de termos como "conquista" e "direitos" na chamada.

Finalmente, vale notar que, no produto concebido pelos editores da Época SP, essa valorização utópica se revela aos leitores/consumidores por meio de uma cena que, no nível narrativo do percurso gerativo de sentido greimasiano, estaria localizada na última fase da "sequência canônica", a sanção. Se as duas mulheres homossexuais simbolizadas pelas jovens modelos tivessem cumprido o percurso narrativo proposto por Greimas, a cena flagrada pela câmera de Christian Gaul exibiria o momento final, em que se distribuem prêmios ou castigos (Fiorin 1989). No nosso caso, temos como prêmios a liberdade, a fruição dos plenos direitos, a vitória alcançada após derrotar, na fase da performance, os vilões (disfóricos) que cruzaram seu caminho: homofobia, religião, conservadorismos... "Se nem sempre aparecem prêmios e castigos na fase da sanção, sempre estará presente a verificação de que a performance aconteceu", afirma Fiorin.

O que veremos a seguir, a partir do estudo da recepção dessa mesma capa (e não mais da enunciação, analisada até aqui), é que uma imagem pode ser interpretada de maneira diametralmente oposta conforme o olhar e a bagagem de quem observa. Basta, para isso, que os elementos semióticos saltem aos olhos e que os interdiscursos aflorem (com base em nossas memórias e referências). De maneira surpreendente, o que é eufórico pode virar disfórico; o utópico, lúdico, e a sanção, manipulação, à medida que o enunciado encontra a circulação.

\section{RECEPÇÃO: FETICHE E PRECONCEITO}

As primeiras críticas à Época SP pipocaram assim que a capa foi divulgada nas redes sociais, na tarde de 28 de março, véspera da chegada da revista às bancas: "Quando olho, vejo um anúncio de produto erótico; infelizmente sempre tentam vincular a 
A foto errada na capa certa: casamento gay, fetichismos visuais e produção de sentido na recepção midiática

de Camilo Vannuchi

comunidade GLBT ao sexo e à promiscuidade", escreveu Ingrid Raigonvan na página da revista no Facebook. "A foto tem um toque de sensualidade proposital, alimenta a libido masculina para aumentar as vendas, porém não reflete a realidade da comunidade homossexual e muito menos a real importância que esse direito representa para nós", registrou outra internauta, Katty Bustamante. A comparação com a Time veio em seguida. "A da Time é boa; a da Época é uma M\#\$\%\#", acusou Axa Paula Sales, que acrescentou: "Pura apelação porno-soft. Ridícula. Colocar uma família gay ou uma real demonstração de afeto seria uma capa boa. Isso aí é lixo."

As críticas se estenderam ao blog Faz Caber, que publicou na mesma tarde um texto narrando como a capa foi produzida. Ali, as acusações eram semelhantes às feitas no Facebook: "A capa é bem bonita, mas não passa a verdadeira aura da história do casamento homossexual. Tá com cara de editorial de beleza (com pegada fetichista) de revista de moda. Deveria ter um clima de afeto e não de sensualidade!", reclamou Raoni Felix. "Nós lutamos para mudar a imagem porca que a sociedade tem da gente e uma revista estraga tudo com uma foto infeliz!", acusou Aggy.

A leitora Vivian arriscou uma análise sociológica em seu comentário: "O conservadorismo prefere duas mulheres se beijando para homem hétero ver", postou. "Infelizmente, essa capa não retrata uma relação lésbica. Parece mais um filme pornô feito para homens. A capa da Time, com pessoas normais vivendo uma relação normal, é que mostra a realidade". Suas observações encontraram coro em outros comentários, que em geral revelam percepções semelhantes. "Se quer falar de um tema (...) mais liberal, em aceitar as diferenças, não se pode fazer uma capa conservadora", escreveu Lucas Patricip. "A Época perdeu a oportunidade de fazer uma capa realmente histórica", afirmou Tony Goes. "Faço coro com os demais comentários: a capa foi um verdadeiro desserviço à causa LGBT", resumiu Cristiano Lins. "Uma imagem fetichista e com forte cunho machista. Em nada se compara ao brilhante trabalho veiculado pela Time".

Esses comentários nos instigaram a investigar por que as boas intenções dos editores foram traduzidas de maneira tão diversa pelos leitores. Em outras palavras, o que fez com que os valores pensados pelos emissores se perdessem na recepção? Onde o caldo entornou? Para encontrar uma resposta, é preciso, primeiramente, buscar auxílio no conceito de circulação. É essa região interdiscursiva, estabelecida no hiato que se forma entre emissão e recepção, que se verificam os deslocamentos responsáveis, ao menos nesse caso, por subverter, na mensagem, os sentidos primordiais pensados ou 
A foto errada na capa certa: casamento gay, fetichismos visuais e produção de sentido na recepção midiática

de Camilo Vannuchi

sugeridos pelos emissores, em favor de novos sentidos, que nem sempre condizem com o que fora projetado por eles ao idealizar a recepção.

Por muito tempo, como nota Antonio Fausto Neto (2010), o estudo da comunicação baseado na teoria dos efeitos concebeu a emissão como soberana na produção de sentido de um enunciado. Em seguida, o pêndulo se inclinou na direção oposta, inaugurando a profusão dos estudos de recepção, que quase sempre concluíam a mesma coisa: os ruídos no processo comunicativo seriam responsáveis por impedir o "correto" processamento, pelo receptor, do sentido conferido ao discurso pelo emissor. Só recentemente os estudiosos da comunicação, ainda de maneira insipiente, passaram a conceber a circulação como um dispositivo de produção de sentido. Ou seja: a recepção deixa de ser entendida tão-somente como um obstáculo para a confirmação do sentido projetado pelo emissor para assumir, ela mesma, co-autoria da produção de sentido. Assim, a produção e a recepção subordinam-se a um novo regime, interdiscursivo, no qual a circulação aparece como "um novo lugar de produção, funcionamento e regulação de sentidos" (Fausto Neto 2010).

Ou seja, a circulação - transformada em lugar no qual produtores e receptores se encontram em "jogos complexos" de oferta e de reconhecimento - é nomeada como dispositivo em que se realiza trabalho de negociação e de apropriação de sentidos, regidos por divergências, e não por linearidades. (...) Nestas condições o âmbito da circulação não seria apenas um conceito que remeteria à noção de intervalo, ou defasagem conforme se supunha antes. Mais que isso, é o âmbito de uma complexa articulação entre "propriedades do discurso proposto e as estratégias de apropriação do sujeito" (Fausto Neto 2010: 63).

É, portanto, no âmbito da circulação que surgem, como bem contextualizado por Fausto Neto, os paradoxos entre o sentido produzido pelos editores e o sentido produzido pelo público leitor (ou parte dele) no episódio aqui pesquisado.

Grosso modo, as críticas negativas à capa da Época SP na ocasião giraram em torno de dois conceitos: fetichismo e machismo. A imagem escolhida, segundo a voz hegemônica nas redes sociais, não representa uma relação homoafetiva real, não gera empatia entre os gays e, no extremo, revela-se sexista e homofóbica ao reproduzir estereótipos associados à homossexualidade: apresentar os gays como promíscuos e libidinosos, jamais como indivíduos amorosos e afetuosos.

O fetichismo é um conceito nebuloso, passível de diferentes traduções. Muitas vezes, vem associado a algum desvio sexual ou erotismo "bizarro", carregado de simbologia pornográfica. Refere-se frequentemente a uma atração pitoresca por itens de ves- 
A foto errada na capa certa: casamento gay, fetichismos visuais e produção de sentido na recepção midiática

de Camilo Vannuchi

tuário (peças de couro, saltos pontiagudos, cintas-ligas...), regiões do corpo fisiologicamente desprovidas de potencial erógeno (pés, pintas, tatuagens...), atitudes e posturas relacionadas ao exercício do poder (sadismo, masoquismo, bondage, dominação...) ou artefatos e instrumentos específicos (algemas, chicotes, correntes, bonecas...). O conceito, no entanto, extrapola os limites da moda e do sexo e, desde o século XIX, pode ser empregado para categorizar toda forma de adoração extrema, irracional, como nos lembra a historiadora Valerie Steele, diretora do Museu do Instituto de Tecnologia da Moda de Nova York, em um livro sobre fetiche publicado pela Universidade Oxford na década de 1990:

O discurso original sobre fetichismo era religioso e antropológico. Tratados de missionários (...) denunciaram as religiões "bárbaras" de pessoas que adoravam "ídolos de madeira e barro". No início do século XIX, o termo fetiche tinha se estendido para se referir a qualquer coisa que fosse irracionalmente adorada. Então uma segunda interpretação, marxista, evoluiu. Karl Marx cunhou a frase "fetichismo de produto", analisando o conceito em termos de falsa consciência e alienação que encontra gratificações espúrias no consumo. Como lhes falta consciência de classe, escreveu Marx, os trabalhadores que produzem objetos com estes atributos outorgam um valor "secreto", o que dá a cada item de consumo a qualidade de um "hieroglifo social" que precisa ser decodificado (Steele 1997: 13).

Curiosamente, esse mesmo duplo-significado da palavra fetiche veste como luva as críticas feitas pelos internautas à capa da Época SP. A um só tempo, o principal "pecado" da publicação foi estampar uma imagem que pode ser qualificada como fetichista tanto do ponto de vista do comportamento sexual (uma imagem provocativa, com elementos sedutores que incitariam ao sexo) quanto do ponto de vista do fetichismo de produto de Marx (no caso, voltado para o consumo dos homens, especialmente dos consumidores de pornografia).

A opção da Época SP, intencional ou não, nem de longe pode ser entendida como um episódio isolado. Ela reflete, como aparece em alguns comentários, prática recorrente no jornalismo e na publicidade, ambos ecoando uma sociedade cada vez mais "fetichizada". Não nos cabe discutir aqui se a disseminação dos fetichismos na mídia é causa ou efeito da "fetichização" da sociedade - ou seja, se foi a superexposição dos fetiches na mídia que influenciou o comportamento social ou se foi o comportamento social que determinou a atuação da mídia. A nós, interessa notar a avalanche de códigos que remetem ao fetichismo, em especial nos grandes centros.

Em Fetichismos visuais: corpos eróticos e metrópole comunicacional (2008), o italiano Massimo Canevacci se debruça sobre o tema e constata um movimento curioso: 
A foto errada na capa certa: casamento gay, fetichismos visuais e produção de sentido na recepção midiática

de Camilo Vannuchi

em razão da superexposição, o fetiche, definido pela tradição semântica como algo anormal, bizarro ou peculiar, torna-se o inverso: cada vez mais normal e constante.

Um crescente abraço fetichista está inundando a comunicação visual com uma elevada perversão normalizada. Em conclusão, é como se (...) o fetichismo e o visual fossem as duas lâminas de uma tesoura que vão se unir no ato final do corte (Canevacci 2008: 20).

E que tipo de código fetichista pode ser reconhecido na capa da Época SP? Canevacci, em sua obra, introduz o conceito de atrator, que muito nos ajuda a abordar essa questão:

Esta dança dos códigos-fetiches é focalizada em (...) detalhes mínimos que determinaram há muito tempo um tipo de adestramento espontâneo para a decodificação por parte dos vários, mutantes e estratificados públicos: o detalhe mínimo constitui um atrator. Uma força semiótica e carnal que atrai e, ao mesmo tempo, é atraída por coágulos de fetichismos visuais (Canevacci 2008: 28).

Nossa avaliação, bem como a exposta em alguns dos comentários estudados, é de que o maior atrator da imagem da capa são os lábios das modelos. Mais especificamente, o batom vermelho. Como o "punctum" de que trata Roland Barthes em A câmara clara, o atrator é esse elemento constitutivo da imagem que, erótico e sedutor, domina a visão e faz com que todo o resto se torne coadjuvante. No processo de produção de sentido, é esse atrator que, de forma totalizante, se sobrepõe aos demais elementos da página para configurar uma mensagem fetichista, sexualizada.

E onde mais, na sociedade contemporânea, duas mulheres sedutoras, de lábios vermelhos, tocam-se de maneira provocativa, na iminência de um beijo, ao mesmo tempo em que nos permitem admirá-las, como voyeurs, se não num filme erótico? Mais do que isso, em que outra circunstância uma das garotas nos lançaria um olhar oblíquo e exibicionista, quiçá convidativo, como se nos incitasse a juntar-nos a elas? Se "o sentido da palavra é totalmente determinado por seu contexto", como definiu Bakhtin (citado por Flores e Teixeira 2005: 50), e se todo discurso dialoga com outros discursos, anteriores a ele, é graças a esse postulado, que inspirou em Bakhtin o conceito de dialogismo, que prospera a comparação com a indústria pornográfica.

Colocando de outra forma: à revelação do atrator batom segue-se um movimento inevitável de produção de sentido que logo contamina toda a cena. Agora, não são mais duas mulheres altivas e soberanas que povoam a imagem, no pleno exercício de seus direitos civis, evidenciando a fase da sanção de Greimas (ver Fiorin 1989), e a valoriza- 
A foto errada na capa certa: casamento gay, fetichismos visuais e produção de sentido na recepção midiática

de Camilo Vannuchi

ção utópica segundo Floch (ver Souza e Santarelli 2008). O que temos é um anúncio erótico, na qual a cena congelada pertence à fase da manipulação, do tipo tentação como se ela nos dissesse: "se você comprar esta revista, poderá se juntar a essas duas garotas e ter muito prazer com elas" -, e com valorização lúdica (categoria de Floch que reúne valores não-utilitários, como sensualidade, diversão e deleite).

Agora, tudo coopera para que o sentido da imagem se inverta, tornando eufórico o que era disfórico (e vice-versa) na intenção original dos enunciadores. Convertidas em mulheres-objetos, com as funções de seduzir e entreter um leitor/consumidor essencialmente masculino e heterossexual, o casal da foto passa a representar não mais as protagonistas soberanas inferidas na emissão, mas duas garotas submissas, que reproduzem estereótipos machistas e conservadores.

Estranhamente, toda essa abordagem se dá exclusivamente em razão da imagem. A chamada de capa tem sua intenção preservada. O texto grafado em corpo grande, à guisa de título, continua transmitindo, na recepção, os mesmos valores e o mesmo conteúdo pretendido pelos editores no momento da enunciação. Aqui, texto e imagem se chocam. A polifonia de Bakhtin se faz presente, portanto, de maneira clássica e elementar: vozes em conflito numa mesma peça, num mesmo enunciado, como sinalizou o russo. No nosso caso, uma polifonia espontânea, não programada, surgida na recepção, precisamente na circulação, a despeito da intenção monofônica do enunciador.

"A polifonia pode ser percebida num texto quando se identificam várias vozes, em oposição aos textos monofônicos, que ocultam os diálogos que os constituem", escreveu Trindade (2012) para expor didaticamente o conceito de Bakhtin. É como se, nas entrelinhas, a capa da Época SP nos dissesse: os gays conquistaram direitos importantes, que devem ser comemorados; mas nós ainda não aprendemos a transportar essas conquistas para o campo visual, para a iconografia, ainda marcada pelos mesmos preconceitos e estereótipos.

\section{CONCLUSÃO: POR UM ESTUDO DA ENUNCIAÇÃO DA RECEPÇÃO JORNALÍSTICA}

O jornalismo é cheio de armadilhas. A publicidade também. No meio editorial, uma capa de revista desempenha função análoga à de uma embalagem e, por essa razão, deve ser igualmente pensada de modo a despertar o interesse do consumidor, conquistar 
A foto errada na capa certa: casamento gay, fetichismos visuais e produção de sentido na recepção midiática

de Camilo Vannuchi

sua confiança, promover a marca, veicular a ideologia da empresa, informar sobre o conteúdo de forma transparente, e, finalmente, convencê-lo a adquirir o produto. Infelizmente, tanto o rótulo quanto a capa encerram-se em si mesmos. Ambos precisam ser claros e certeiros, breves e exatos, sem deixar margem a dúbia interpretação nem carecer de explicações. Não há ocasião para outros complementos.

Tradicionalmente, os estudos da enunciação publicitária têm se restringido à análise dos elementos semióticos e constitutivos do discurso com base na peça veiculada: ou seja, do ponto de vista do enunciador. Neste artigo, usamos uma capa para demonstrar algo que um estudo de recepção publicitária também seria capaz de mostrar: o hiato entre emissão e recepção e o que pode acontecer com a mensagem em sua circulação. Nele, conclui-se pela relevância dos estudos de circulação, editorial ou publicitária, não apenas para se verificar a eficácia de uma embalagem, mas também para se criar um repertório que possa ser utilizado em enunciações futuras.

A recepção como circulação, tanto jornalística quanto publicitária, deve ser concebida como protagonista do trabalho da mídia, ocupando lugar de destaque nos estudos de enunciação, produção de sentido e práticas de consumo, uma vez que é no receptor que toda capa (e todo anúncio) realiza seu objetivo. Uma abordagem da recepção pode contribuir para se repensar a emissão. Trindade (2008b), desde os anos 2000, defende a conveniência de se desenvolver uma teoria da enunciação da recepção publicitária. $\mathrm{O}$ conceito provoca estranheza ao primeiro contato, por conter um aparente paradoxo temporal, dado que enunciação e recepção ocupam momentos distintos no processo comunicativo. Sua proposta, no entanto, é que possamos refletir sobre a enunciação publicitária no pólo da recepção. O objetivo não é teorizar sobre a recepção publicitária, mas "promover a discussão sobre a enunciação estendida à produção de sentido do receptor". Assim,

\footnotetext{
...buscamos a formulação de diretrizes para a compreensão do fluxo da recepção publicitária nos contextos e situações de suas ocorrências.(...) A principal conclusão que podemos extrair dessa reflexão é a possibilidade de entender o receptor da publicidade como um sujeito enunciatário em seus próprios contextos da vida ordinária (Trindade 2008b: 35).
}

Acreditamos que o jornalismo pode se beneficiar do mesmo tipo de estudo, uma vez que o receptor da informação jornalística - e dos produtos editoriais jornalísticos em geral - é também um sujeito enunciatário em seus próprios contextos. Ao ler um título, uma legenda, ou observar uma foto, uma capa, ele elabora significados e produz 
A foto errada na capa certa: casamento gay, fetichismos visuais e produção de sentido na recepção midiática

de Camilo Vannuchi

sentido, usando-se de seu próprio repertório dialógico, de suas memórias e interdiscursos, apoiando-se largamente nos mesmos elementos semânticos, textuais ou imagéticos, empregados na emissão, eventualmente com intenções distintas. Conhecer como se comportam os receptores da informação jornalística, descobrir de que maneira eles resignificam os elementos utilizados pelos jornais e revistas ao produzirem seus discursos, são tarefas essenciais para que editores e diretores, designers e redatores, possam aprender com eles.

\section{REFERÊNCIAS BIBLIOGRÁFICAS}

CANEVACCI, M. Fetichismos visuais: corpos erópticos e metrópole comunicacional. São Paulo: Ateliê, 2008.

DREHLE, D. "How gay marriage won", in Time, Nova York, 28/3/2013. Disponível em: <http://swampland.time.com/2013/03/28/how-gay-marriage-won/>. Acesso em: 5/6/2013.

FAUSTO NETO, A. "As bordas da circulação...", in Revista Alceu, no 20, vol. 10, Rio de Janeiro: PUC-RJ, jan-jul 2010: 55-69. Disponível em: $<$ http://revistaalceu.com.puc-rio.br/media/Alceu 20_Neto.pdf $>$. Acesso em: 6/9/2013.

FIORIN, J. Elementos de análise do discurso. São Paulo: Contexto, 1989: 11-38.

FLORES, V.; TEIXEIRA, M. Introdução à linguística da enunciação. São Paulo: Contexto, 2005.

MARQUES, M. "Começa a valer em SP norma que regulamenta casamento civil de gays", in Faz Caber, São Paulo, 28/3/2013. Disponível em: <http://colunas.revistaepoca.globo.com/fazcaber/ 2013/03/28/epoca-spcasamento-gay/>. Acesso em: 12/6/2013.

MAINGUENEAU, D. Novas tendências em análise do discurso. Campinas: Pontes/Unicamp, 1989: 111-126.

RIBEIRO, A.; COLLETTA, D. "Enfim, a certidão de casamento", in Época São Paulo, São Paulo, 29/3/2013. Disponível em: <http://epocasaopaulo.globo.com/vidaurbana/enfim-a-certidao-de-casamento/> . Acesso em: 5/6/2013.

STEELE, V. Fetiche: moda, sexo \& poder. Rio de Janeiro: Rocco, 1997. 
A foto errada na capa certa: casamento gay, fetichismos visuais e produção de sentido na recepção midiática

de Camilo Vannuchi

SOUZA, S.; SANTARELLI, C. "Contribuições para uma história da análise da imagem no anúncio publicitário", in Revista Brasileira de Ciências da Comunicação, $\mathrm{n}^{\mathrm{o}} 1$, vol. 31, São Paulo: Intercom, jan-jul 2008: 133-156.

TRINDADE, E. "Recepção publicitária e práticas de consumo", in Revista Fronteiras, $n^{\circ}$ 10, vol. 2, São Leopoldo: Unisinos, mai-ago 2008: 73-80 (2008a).

TRINDADE, E. "Diretrizes para uma teoria da enunciação da recepção publicitária", in Revista Brasileira de Ciências da Comunicação, $\mathrm{n}^{\circ}$ 2, vol. 31, São Paulo: Intercom, jul-dez 2008: 35-54 (2008b).

TRINDADE, E. Propaganda, identidade e discurso. Porto Alegre: Sulina, 2012: 58106.

Artigo submetido: 12/09/2013

Artigo aprovado: 28/11/2013 